\title{
HEREDITARY THROMBOPHILIA IN RECURRENT IVF FAILURE
}

\author{
Ezzat El Sobky ${ }^{1}$, Shaimaa Gad Ragheb ${ }^{1}$ and Gina Mazhar Deif ${ }^{2}$
}

\author{
${ }^{1}$ Medical genetic Department \\ Faculty of Medicine - Ain \\ Shams University \\ ${ }^{2}$ Sunrise Fertility Center -IVF \\ Laboratory Department \\ Corresponding author \\ Gina Mazhar Deif \\ Mobile: : +2 01274224404 \\ E.mail: \\ ginagorgy@gmail.com \\ Received: 6/4/2021 \\ Accepted: 4/5/2021
}

Online ISSN: 2735-3540

\begin{abstract}
:
Background: The predominant part of IVF cycles results in embryo transfer, but only about one third of all cycles reach clinically achieved pregnancy. This is evidence that most embryos failed in an early stage of pregnancy achievement. Recurrent implantation failure after IVF procedures emphasize the clinical importance of this crucial step in assisted reproductive technology. Repeated unsuccessful IVF attempts force efforts to investigate the firm mechanism of the implantation and to find approach to increase pregnancy outcome success. Plenty of factors have been recognized to affect either success, or failure rate of IVF embryo transfer. Maternal side factors include age, parity, hormonal levels before stimulation, antral follicles count, endometrial thickness and quality of transformed endometrium. Other factors, having functions in coagulation and fibrinolysis cascades, were found to be connected with the transformation processes in the endometrium during the implantation.
\end{abstract}

Aim of work: The aim from this study is to evaluate the relation between hereditary thrombophilia and recurrent IVF failure. This will be done by comparing the prevalence of thrombophilia factors mutation in patients with repeated IVF failure and in normal population.

Methods: Thirty patients with recurrent IVF failure underwent genetic testing of thrombophilia markers by PCR: Factor II prothrombin mutation, Factor $V$ leiden mutation (FVL), and Methylene tetrahydrofolate reductase (MTHFR) mutation.

Results: $13.3 \%$ were tested positive for factor $V$ mutation G1619A, 56.7\% were positive for MTHFR c667t mutation. While in healthy normal Mediterranean population the percentage of mutation were $3.7 \%$ for FVL mutation and $11.1 \%$ for MTHFR mutation.

Conclusion: hereditary thrombophilia may be considered as a factor in recurrent IVF failure, proper management is to be considered.

Key words: Recurrent IVF failure, hereditary thrombophilia, factor V mutation, MTHFR mutation, factor II prothrombin mutation.

\section{INTRODUCTION:}

Despite of the large number of embryo transfer in the majority of infertility centers, only one third of all IVF cycles reach clinically achieved pregnancy ${ }^{(1)}$.
The largest percentage of failed IVF cycles are due to lack of implantation which in some patient occurs repeatedly ${ }^{(2)}$.

Recurrent IVF failure is defined as failure to achieve pregnancy following 3 or more cycles ${ }^{(3)}$. 
The possible causes of repeated implantation failure have been widely investigated as to improve endometrial receptivity and vascularity to achieve IVF success ${ }^{(4)}$.

Hereditary thrombophilia may play a role in implantation failure by impairing the initial vascularization process needed for embryo adhesion in the endometrium. The role of thrombophilia in recurrent implantation failure following IVF treatments is thought to be through mechanisms similar to those seen in recurrent miscarriage and has been the focus of research efforts. It has been hypothesized that invasion of maternal vessels by syncytiotrophoblast can be affected by localized thrombosis at the implantation site, leading to IVF failure ${ }^{(5)}$.

In addition, the thrombomodulin-protein C system is essential (as an inhibitor of coagulation and fibrinolysis), to prevent over production of tissue factor which in turn leads to generation of thrombin and ultimately fibrin degradation products that are toxic to trophoblast cells ${ }^{(6)}$. The present study was conducted to determine role of hereditary thrombophilia in such repetitive IVF failures.

\section{PATIENTS AND METHODS:}

The study enrolled 30 consecutive patients with recurrent IVF failure. They were recruited from sunrise fertility center. All patients aged from 20-40 years old.

PCR testing were done for this patients after their consent for thrombophilia markers:

- Factor V Leiden mutation

- Methylene tetrahydrofolate reductase mutation

- Prothrombin factor II mutation
The patients have been collected from sunrise fertility center between the period of 2017-2018. All patients aged from 20-40 years old. Percentage of thrombophilia was compared to the percentage in normal healthy Mediterranean population.

\section{Inclusion criteria:}

1. Woman age $<40$ years

2. Body mass index $<35 \mathrm{~kg} / \mathrm{m}^{2}$

3. Recurrent IVF failure was defined as at least three consecutive failed IVF cycles. Failed IVF cycle was defined as failure to achieve clinical pregnancy in a cycle in which at least three good quality embryos (grade I or II) were transferred. Indications for IVF were male factor, ovulatory factor, tubal factor and unexplained infertility. All fertilizations were performed by intra cytoplasmic sperm injection (ICSI).

Conventional RM/RIF study showing no abnormalities. Conventional RM/RIF study included all of the following woman and man karyotypes, vaginal ultrasonography, hysterosalpingography, hyster-oscopy, sperm DNA fragmentation, homocysteinemia, thyroid hormones, and fasting glucose.

\section{Exclusion criteria:}

1. Polycystic ovarian syndrome

2. Autoimmune disorders

3. History of preeclampsia, cardiac disease or thrombosis.

4. Known chromosomal abnormalities

5. Positive results of anti-phospholipid antibodies

\section{RESULTS:}

The median number of failed ICF cycles was 3; ranging from 3 to 7 (Diagram 1). 


\section{Hereditary Thrombophilia In Recurrent Ivf Failure}

Table 1: Frequency of thrombophilic factors in the studied group

\begin{tabular}{|l|c|c|}
\hline & Number & Percentage \\
\hline Factor V Leiden G1691 $\rightarrow$ A mutation & 4 & 13.3 \\
\hline Heterozygous & 4 & 13.3 \\
\hline Homozygous & 0 & 0.0 \\
\hline Methylene tetrahydrofolate reductase C677 $\rightarrow \mathrm{T}$ & 17 & 56.7 \\
\hline Heterozygous & 16 & 53.3 \\
\hline Homozygous & 1 & 3.3 \\
\hline Prothrombin G20210A gene & 0 & 0.0 \\
\hline & & \\
\hline
\end{tabular}

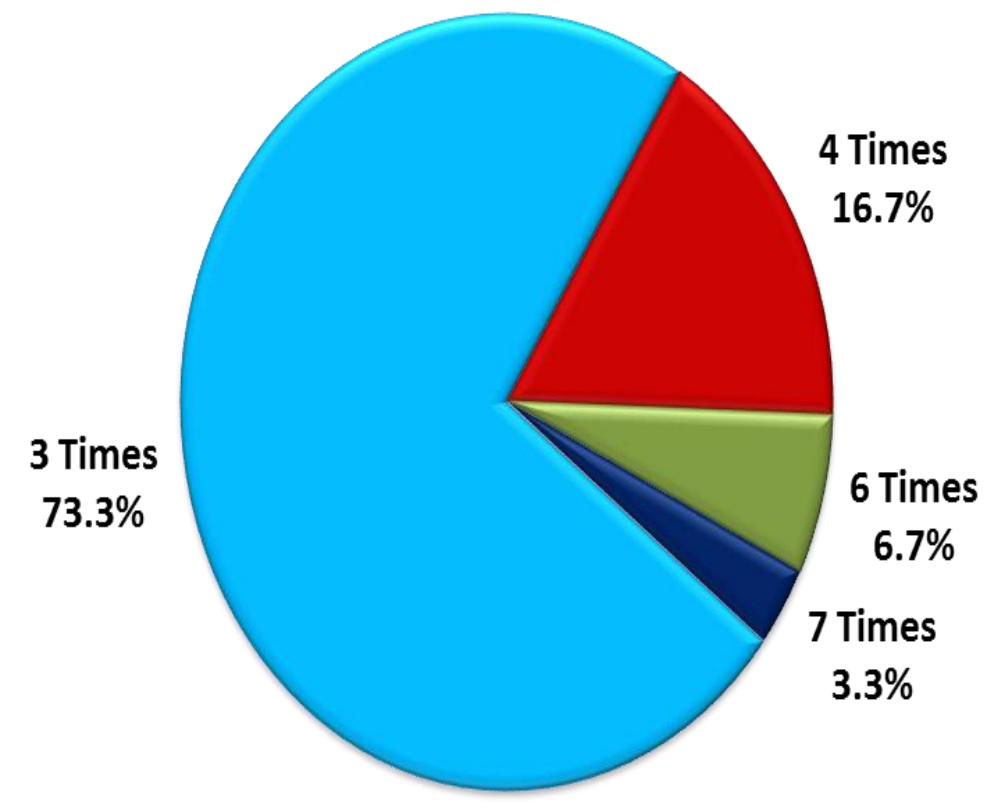

Diagram (1): Distribution of the number of IVF failures in the studied group

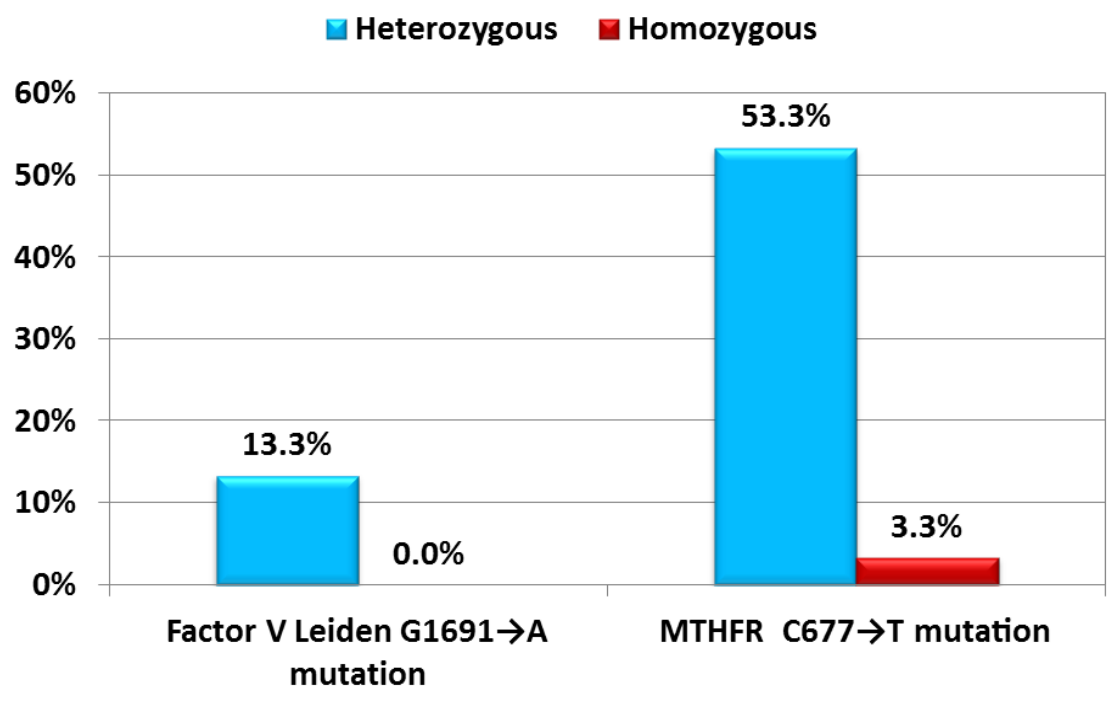

Diagram (2): Frequency of Factor V Leiden G1691 $\rightarrow$ A and MTHFR C677 $\rightarrow$ T mutations in the studied group. 
All patients were negative for prothrombin mutation G20210 $\rightarrow$ A. Factor V Leiden $\mathrm{G} 1691 \rightarrow$ A mutation was detected in 4 patients (13.3\%); all of them were heterozygos for the mutant allele. Methylene tetrahydrofolate reductase $\quad \mathrm{C} 677 \rightarrow \mathrm{T}$ mutation was detected in 17 patients (56.7\%); only one of them was homozygous for the mutant allele and the rest were heterozygous (Table 1).

Age was not related to the presence of thrombophilia $(p=0.249)$. Age of patients with thrombophilia was $32.3 \pm 3.6$ years compared to $33.8 \pm 4.4$ years of those without thrombophilia.

\section{DISCUSSION:}

The results of this study revealed a higher prevalence of inherited thrombophilia in women with repeated IVF failure: Where percentage of factor $\mathrm{V}$ mutation was $13.3 \%$ and MTHFR mutation was $56.7 \%$, compared to general healthy population in Mediterranean area which were: $3.7 \%$ for factor $\mathrm{V}$ mutation and $11.1 \%$ for MTHFR mutation ${ }^{(7)}$. And compared to Egyptian healthy population for factor5 which was 9.6 reported by $\boldsymbol{U l u}$ et $\boldsymbol{a l} .{ }^{(8)}$. Similar findings were found by an Iranian research which also supported relation of hereditary thrombophilia and repeated IVF failure ${ }^{(9)}$. Thrombophilic genetic mutations increase the tendency toward coagulation and thromboembolic disease ${ }^{(10)}$. Of the two main recognized genetic mutations factor $\mathrm{V}$ Leiden (FVL) mutation involves a guanineto-adenine substitution (G/A) at nucleotide 1691 in exon 10, which results in synthesis of a defective factor $\mathrm{V}$ molecule, resistant to cleavage by activated protein $C^{(11,12)}$. Sequence variation of a $\mathrm{G}$ to $\mathrm{A}$ transposition in the 3-untranslated region of the prothrombin gene (FII; position 20210) results in increased plasma prothrombin and a two-to-four fold increased risk for thromboembolic disease ${ }^{(13,14)}$. Methylene tetrahydrofolate reductase (MTHFR) enzyme involvement in the regulation of homocysteine concentration is also involved as a risk factor for thrombophilia ${ }^{(15)}$. In the MTHFR gene, there are two relatively common single-nucleotide polymorphisms associated with reduced enzyme activity and hyperhomocyteinemia; $\mathrm{C} / \mathrm{T}$ in exon 4 at nucleotide 677 leading to Ala222Val substitution; and A/C in exon 7 at nucleotide 1298 , leading to Glu429Ala substitution ${ }^{(16)}$.

This fact reinforces the association between thrombophilia vascular effects and repeated implantation failure in IVF cycles. Also, previous studies revealed that patients with inherited thrombophilia suffer from other complications such as abortion, preeclampsia, fetal growth affection and stillbirth $^{(17-19)}$.

A possible mechanism of implantation failure may be the thrombosis of maternal blood vessels. Early placentation may be caused by similar mechanism ${ }^{(17-18)}$. However, other mechanisms may be responsible too like the damage of decidual or chorionic vessels and reduction of trophoblast invasiveness ${ }^{(20-21)}$. Evaluation of thrombophilia in patient with multiple IVF failure may help in proper management of these cases and increase the IVF success.

\section{Conclusion:}

Hereditary thrombophilia may have a role in recurrent IVF failure as it is more prevalent in the studied group than in normal healthy population.

\section{Recommendations:}

We recommend thrombophilia factors testing in patient with multiple IVF failure for proper management.

\section{REFERENCES:}

1. Simon A, Laufer N (2012): Repeated implantation failure: clinical approach. Fertil Steril; 97:1039-1043. 
2. Di Micco P, D'Uva M, Lodigiani C, Rota LL (2010): Thrombophilia and repeated in vitro fertilisation and embryo transfer failure: an open issue. Thromb Haemost; 103:472-473.

3. Tan BK, Vandekerckhove P, Kennedy R, Keay SD (2005): Investigation and current management of recurrent IVF treatment failure in the UK. BJOG; 112:773-780.

4. Margalioth EJ, Ben-Chetrit A, Gal M, Eldar-Geva $T$ (2006): Investigation and treatment of repeated implantation failure following IVF-ET. Hum Reprod; 21:30363043.

5. Nelson SM, Greer IA (2008): The potential role of heparin in assisted conception. Hum Reprod Update; 14:623-45.

6. Isermann B, Sood R, Pawlinski R, Zogg M, Kalloway S, Degen JL, et al. (2003): The thrombomodulin-protein C system is essential for the maintenance of pregnancy. Nat Med; 9:331-7.

7. Chatzidimitriou $\mathrm{M}$, chatzidimitriou $\mathrm{D}$, Mavridou M, Anetakis C, Chatzopoulou F, Lialiaris T, et al. (2017): Thrombophilic gene polymorphisms and recurrent pregnancy loss in greek women. Int $\mathrm{J}$ Lab Hematol; 39:590-5.

8. Ulu A, Elsobky E, Elsayed M, Yıldız Z, Tekin M, Akar N (2006): Frequency of five thrombophilic polymorphisms in the Egyptian population. Turk J Haematol; 23(2):100-3.

9. Safdarian L, Najmi Z, Aleyasin A, Aghahosseini M, Rashidi M, Asadollah S (2014): Recurrent IVF failure and hereditary thrombophilia. Iran J Reprod Med; 12(7):467-70.

10. Wouters MG, Nováková IR, Steegers EA (2003): Thrombophilia and the prevention of thromboembolic complications during pregnancy and the puerperium. Ned Tijdschr Geneeskd; 147:1060-6.

11. Huber S, McMaster KJ, Voelkerding KV (2000): Analytical evaluation of primer engineered multiplex polymerase chain reaction-restriction fragment length polymorphism for detection of factor $\mathrm{V}$ Leiden and prothrombin G20210A. J Mol Diagn JMD; 2:153-7.
12. Ranguelov RD, Rosenthal N, Bromley C, Vasef MA (2002): Detection of factor V leiden and prothrombin gene mutations in patients who died with thrombotic events. Arch Pathol Lab Med; 126:1193-6.

13. Gerhardt A, Scharf RE, Beckmann MW, Struve S, Bender HG, Pillny M, et al. (2000): Prothrombin and factor V mutations in women with a history of thrombosis during pregnancy and the puerperium. $\mathrm{N}$ Engl J Med; 342:374-80.

14. Kupferminc MJ (2003): Thrombophilia and pregnancy. Reprod Biol Endocrinol RBE; $1: 111$.

15. Wald DS, Law M, Morris JK (2002): Homocysteine and cardiovascular disease: evidence on causality from a meta-analysis. BMJ; 325:1202.

16. Botto LD, Yang Q (2000): 5,10Methylenetetrahydrofolate reductase gene variants and congenital anomalies: a HuGE review. Am J Epidemiol; 151:862-77.

17. Kupferminc MJ, Eldor A, Steinman N, Many A, Bar-Am A, Jaffa A, et al. (1999): Increased frequency of genetic thrombophilia in women with complications of pregnancy. N Engl J Med; 340:9-13.

18. Rey E, Kahn SR, David M, Shrier I (2003): Thrombophilic disorders and fetal loss: a meta-analysis. Lancet; 361:901-908.

19. Kovalevsky G, Gracia CR, Berlin JA, Sammel MD, Barnhart KT (2004): Evaluation of the association between hereditary thrombophilias and recurrent pregnancy loss: a meta-analysis. Arch Intern Med; 164:558-563.

20. Mousa HA, Alfirevic1 Z (2000): Do placental lesions reflect thrombophilia state in women with adverse pregnancy outcome? Hum Reprod; 15:1830-1833.

21. Rand JH, Wu XX, Guller S, Scher J, Andree HA, Lockwood CJ (1997): Antiphospholipid immunoglobulin G antibodies reduce annexin- $\mathrm{V}$ levels on syncytiotrophoblast apical membranes and in culture media of placental villi. Am J Obstet Gynecol; 177:918923. 


\section{Ezzat El Sobky, et al.,}

\section{التهاب الوريد الخثاري و تعدد فثل أطفال الانابيب \\ عزت السبكي، شيماء جاد ، جينا مظهر ضيف}

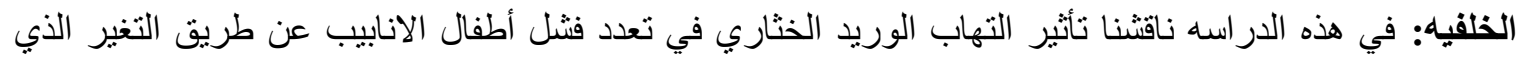

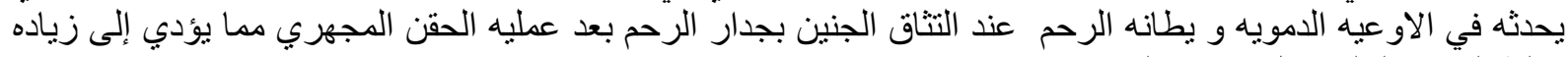
تجلط الدم و بالتالي فثل حدوث الزيه الزرع الزع

الههف: تهدف هذه الدراسه الي توضيح حقيقه ان يكون التهاب الوريد الخثاري الور اثي سببا في تعدد فشل أطفال

المرضى و الطرق: لقد قمنا بعمل هذه الدر اسه على • ب مريضه تم اختبار هم عشو ائي من مركز صن رايز للخصوبه

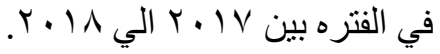
جميع المرضى بين • ب الي • ع سنه النتائج: لقد كان لهذا استغلال احصائ في معدل وجود التهاب الوريد الختاري في المرضى الذين الذين يعانون من تكرار فثل أطفال الانابيب مقارنه بمعدل حدوثه في السكان العاديين الاصحاء. الاستنتاج: نستنتج وجوب عمل تحاليل التهاب الوريد الخثاري الور اثي لجميع حالات تعدد فثل أطفال الانابيب. 